\title{
HYPONATREMIA AS A FIRST SIGN OF SMALL CELL LUNG CANCER: A CASE REPORT
}

\author{
ILK BULGUSU HIPONATREMI OLAN AKCIĞERIN KÜÇÜK HÜCRELI KARSINOMU: \\ OLGU SUNUMU
}

\author{
Emel BAYRAK¹ (D), Kayser ÇAĞLAR² (D) \\ Losev Losante Child and Adult Hospital, 'Department of Internal Medicine, ${ }^{2}$ Department of Nephrology, Ankara, Turkey
}

ORCID IDs of the authors: E.B. 0000-0001-8003-9391; K.Ç. 0000-0002-1428-8880

Cite this article as: Bayrak E, Caglar K. Hyponatremia as a first sign of small cell lung cancer: a case report. J Ist Faculty Med 2020;83(4):451-3. doi: 10.26650/IUITFD.2019.0079

\begin{abstract}
A 62-year- old woman with a history of hypertension and diabetes mellitus was admitted to the emergency department because of headache, weakness, insomnia and impaired balance. Severe hyponatremia was detected and patient was admitted to the hospital. The drugs that could lead to hyponatremia were stopped. Additional investigations were made because of the persistence of hyponatremia. After the diagnosis of inappropriate $\mathrm{ADH}$ syndrome computed tomography of the chest was performed which revealed a pulmonary mass. The histopathological test revealed small-cell carcinoma of the lung.
\end{abstract}

Keywords: Hyponatremia, inappropriate ADH syndrome, lung neoplasms

\section{ÖZET}

Hipertansiyon ve diyabetes mellitus tanıları olan altmış iki yaşındaki kadın hasta; halsizlik, uykusuzluk, dengesizlik ve baş ağrısı yakınmaları ile acil servise başvurdu. Yapılan tetkiklerinde ciddi hiponatremi saptanan ve hastaneye yatırılan hasta hiponatremiye yol açabilecek ilaçları kesilerek takip edildi. Hiponatremisi devam eden hastada yapılan incelemelerde uygunsuz antidiüretik hormon $(\mathrm{ADH})$ sendromu saptanarak çekilen torax tomografisinde akciğerde kitle tespit edildi ve histopatolojik inceleme akciğerin küçük hücreli karsinomu olarak rapor edildi.

Anahtar Kelimeler: Hiponatremi, uygunsuz ADH sendromu, akciğer kanseri

\section{INTRODUCTION}

Hyponatremia is the most common electrolyte disorder in clinical practice and may be asymptomatic or lead to life-threatening clinical conditions. One of the factors causing hyponatremia is inappropriate ADH syndrome and it may develop as a paraneoplastic syndrome. The case of a patient with lung cancer who first presented with hyponatremia is discussed in this case report.

\section{CASE PRESENTATION}

A 62-year-old female patient was admitted to the emergency department with complaints of high blood pressure, increasing fatigue in recent days, difficulty in main- taining balance during walking, headache and insomnia. She did not complain of hemoptysis, cough, weight loss, fever, chest pain or dyspnea. Her chest was clear on oscultation. Cardiac examination revealed a regular heart rate. Pretibial edema and lymphadenopathy were not detected. Main laboratory tests performed in the emergency department of the patient are glucose: $102 \mathrm{mg} / \mathrm{dl}$, sodium: $115 \mathrm{mEq} / \mathrm{L}$, potassium: $4.67 \mathrm{mEq} / \mathrm{L}$, creatinine: $0.60 \mathrm{mg} / \mathrm{dl}$, calcium: $8.60 \mathrm{mg} / \mathrm{dl}$, hemoglobin: $13.4 \mathrm{~g} / \mathrm{dl}$.

Her medical history included hypertension, type II diabetes mellitus and history of smoking. Medications included telmisartan / hydrochlorothiazide, metformin, seratonin reuptake inhibitor (SSRI) and metoprolol.

Corresponding author/iletişim kurulacak yazar: emel.bayrak@gmail.com

Submitted/Başvuru: 18.09.2019 • Revision Requested/Revizyon Talebi: 07.01.2020 •

Last Revision Received/Son Revizyon: 08.01.2020 • Accepted/Kabul: 11.02.2020 • Published Online/Online Yayın: 14.05 .2020

(C)Telif Hakkı $2020 \mathrm{~J}$ Ist Faculty Med - Makale metnine jmed.istanbul.edu.tr web sayfasından ulaşılabilir.

(C) Copyright 2020 by J Ist Faculty Med - Available online at jmed.istanbul.edu.tr 
At first the patient was given $3 \% \mathrm{NaCl}$ infusion due to severe low levels of serum sodium as well as complaints of restlessness and headache. Antihypertensives were switched to calcium channel blockers, and thiazide and SSRI inhibitor were stopped. No significant mass lesion or active infiltration were detected on chest radiography. The patient did not agree to having the recommended Torax CT scan. She was discharged from the hospital when the sodium level increased to $128 \mathrm{meq} / \mathrm{L}$. 10 days after her discharge she was seen again at outpatient clinic and found to have hyponatremia and admitted to the hospital. The laboratory values during the hospitalization period were as follows: serum sodium: $118 \mathrm{meq} / \mathrm{L}$, serum potassium: $5.04 \mathrm{meq} / \mathrm{L}$, creatinine: $0.69 \mathrm{mg} / \mathrm{dl}$, uric acid: $1.60 \mathrm{mg} / \mathrm{dl}$, urine sodium: $48 \mathrm{meq} / \mathrm{L}$, urine osmolality: 351 mosm $/ \mathrm{kg}$, serum osmolality: 243 mosm $/ \mathrm{kg}$.

Upon finding low serum osmolality, high urine osmolality, high urine sodium levels, and clinical euvolemia, and in the absence of renal, pituitary, adrenal and thyroid diseases, inappropriate ADH syndrome was diagnosed and fluid restriction and $3 \% \mathrm{NaCl}$ were applied to the patient. Although she did not complain of any of the pulmonary symptoms and despite the anterior-posterior chest plain film not having any evidence of active pulmonary disease, CT of the thorax was performed for the aetiology consideration of inappropriate ADH syndrome (Figure 1). CT of the thorax revealed a peripheral lobulated contoured pulmonary nodule in the lower lobe of superior segment and lesions compatible with enlarged lymph nodes in the mediastinal area suggesting local advanced stage of primary malignancy. PET CT was performed and revealed hypermetabolism areas defined in the superior segment of the lower lobe of the right lung and mediastinum were found to be compatible with malignant metastatic processes. Histopathological sampling was recommended for primary lung malignancies. Biopsy of the mass revealed small

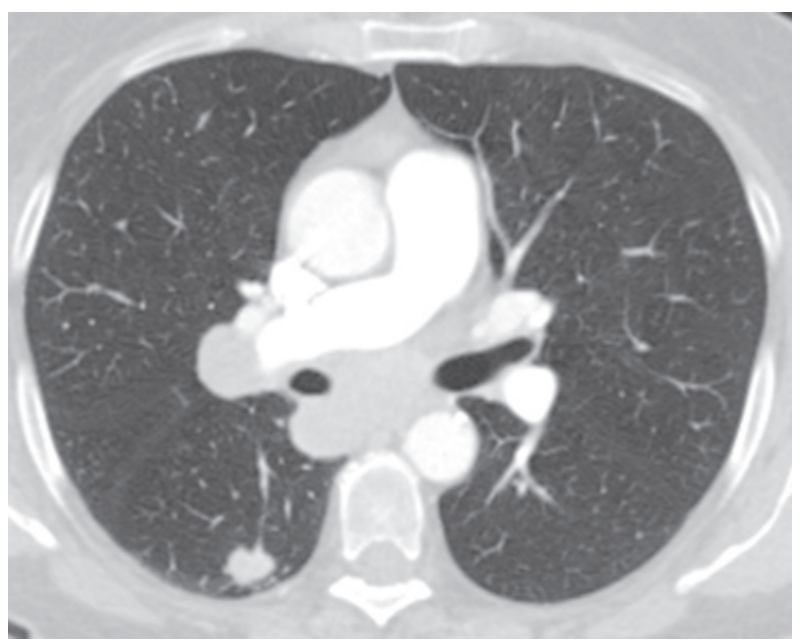

Figure 1: Thorax CT image. cell carcinoma of the lung. There was no metastasis. The patient provided written informed consent for publication.

\section{DISCUSSION}

We report here a case of small cell carcinoma of the lung whose first presentation was compatible with inappropriate ADH syndrome. Hyponatremia, defined as serum sodium concentration below $135 \mathrm{mEq} / \mathrm{L}$, is the most common electrolyte disorder in clinical practice. Hyponatraemia is primarily a disorder of water balance, with a relative excess of body water compared to total body sodium and potassium content. It is usually associated with a disturbance in the antidiuretic hormone (1). Detailed history and physical examination were required to evaluate hyponatremia; electrolite-rich fluid loss due to diuretic use or gastrointesinal looses and the medication that may cause hyponatremia should be looked for. In the physical examination, the presence of edema might be an indicatation of diseases that may lead to hyponatremia such as heart failure, chronic liver disease and renal failure. The presence of signs of thyroid disease or adrenal insufficiency, pulmonary disease, central nervous system disease, and malignancy should be also investigated (2).

In the present case, because the use of certain drugs can cause hyponatremia such as thiazide and SSRI, these agents were immediately discontinued. Although hyponatremia usually occurs in the first weeks, some patients may develop it months later. SSRI inhibitors may also cause hyponatremia by causing inappropriate ADH syndrome (3). In our case, these agents were thought to be aetiologic factors, but the lack of improvement in hyponatremia after termination of these agents required further investigation. Laboratory examinations revealed that the serum osmolality of the patient was low and urine osmolality was found to be high, but adrenal and thyroid functions were normal. When evaluated together with other findings, it meets the criteria of inappropriate ADH syndrome (1). Although the chest X-ray was found to be normal, lung malignancy was detected after tomographic examination. The most common cancers associated with hyponatremia are various forms of lung cancer. The most common causes of hyponatremia in cancer patients are both the syndrome of inappropriate antidiuretic hormone secretion [syndrome of inappropriate antidiuretic hormone $(\mathrm{ADH})]$ and volume depletion (4). In this study, we report on a case presenting with hyponatremia as the first sign of small cell lung cancer. Because of the aggressive nature of the disease, the most common manifestation of small cell carcinoma of the lung is a metastatic one. Approximatelly $70 \%$ of patients present with metastatic disease (5).

Therefore, identifying the disease in earlier stages is very important. Because of the limitations of the screening guidelines, physicians should be suspicious of possible early symptoms or abnormal laboratory values. 


\section{CONCLUSION}

Hyponatremia due to inappropriate $A D H$ syndrome is rare in the onset of malignancy. In our case, by following hyponatremia, we detected a small cell lung cancer when the chest X-ray was normal and neither pulmonary symptoms nor other organ metastasis had developed. The malignancy factor should not be forgotten in the diagnostic evaluation of hyponatremia.

CT of the thorax revealed a peripheral lobulated contoured pulmonary nodüle in the lower lobe of superior segment and lesions compatible with enlarged lymph nodes in the mediastinal area suggesting primary malignancy.

Etik Komite Onayı: Etik komite onayı alınmamıştır. (Olgu sunu$\mathrm{mu})$.

Bilgilendirilmiş Onam: Katılımcılardan bilgilendirilmiş onam alınmıştır.

Hakem Değerlendirmesi: Dış bağımsız.

Yazar Katkıları: Çalışma Konsepti/Tasarım- E.B., K.Ç.; Yazı Taslağı- E.B., K.Ç.; Son Onay ve Sorumluluk- E.B., K.Ç.; Süpervizyon- K.Ç.; Author Contributions: Conception/Design of StudyE.B., K.Ç.; Drafting Manuscript- E.B., K.Ç.; Final Approval and Accountability- E.B., K.Ç.; Supervision- K.Ç.

Çıkar Çatışması: Yazarlar çıkar çatışması beyan etmemişlerdir.

Finansal Destek: Yazarlar finansal destek beyan etmemişlerdir.
Ethics Committee Approval: This study was not approved by an ethical committee. (Case Report).

Informed Consent: Written consent was obtained from the participants.

Peer Review: Externally peer-reviewed.

Author Contributions: Conception/Design of Study- E.B., K.Ç.; Drafting Manuscript- E.B., K.Ç.; Final Approval and Accountability- E.B., K.Ç.; Supervision- K.Ç.

Conflict of Interest: Authors declared no conflict of interest.

Financial Disclosure: Authors declared no financial support.

\section{REFERENCES}

1. Spasovski G, Vanholder R, Allolio B, Annane D, Ball S, Bichet $D$, et al.; on behalf of the Hyponatraemia Guideline Development Group. Clinical practice guideline on diagnosis and treatment of hyponatraemia. Nephrol Dial Transplant 2014:29(Suppl.2):ii1-ii39. [CrossRef]

2. Sterns RH, Diagnostic evaluation of adults with hyponatremia. In: UpToDate, Emmett M(Ed), UpToDate, Waltham, MA. (Accessed on July 19, 2019.)

3. Rawal G, Kumar R, Yadav S. Severe hyponatremia associated with escitalopram, J Family Med Prim Care 2017;6(2):453-4. [CrossRef]

4. Kitchlu A, Rosner M Hyponatremia in patients with cancer. Current Opinion in Nephrology and Hypertension 2019;8(5):433-40. [CrossRef]

5. Molina JR, Yang P, Cassivi SD, Schild SE, Adjei AA. Non-small cell lung cancer: epidemiology, risk factors, treatment, and survivorship. Mayo Clin Proc 2008;83(5):584-94. [CrossRef] 